\title{
Biochar addition affected nutrient leaching and litter decomposition rates in boreal sandy soils
}

\author{
Sanna Saarnio ${ }^{1,2}$ and Riitta Kettunen ${ }^{1}$ \\ ${ }^{1}$ Department of Environmental and Biological Sciences, University of Eastern Finland, Box 111, FI-80101 Joensuu, Finland \\ ${ }^{2}$ Current address: Natural Resources Institute Finland, Yliopistokatu 6, 80130 Joensuu, Finland \\ e-mail: sanna.saarnio@luke.fi
}

\begin{abstract}
Effects of biochar addition on litter decomposition rates, nutrient leaching and soil moisture were tested in two boreal agricultural soils; a sandy till and a medium fine sand. Three litter bags were buried in soil basins, which were stored in the dark for 31 and 19 weeks in the sandy till experiment and medium fine sand experiment, respectively. Once per each temperature period, the soil was saturated in order to collect excess water for nutrient analyses. Biochar increased the decomposition rate of $\mathrm{N}$-rich litter but did not affect the decomposition of $\mathrm{N}$-poor litter. $\mathrm{PO}_{4}^{3-}-\mathrm{P}$ and $\mathrm{NO}_{2}^{-}-\mathrm{N}$ were released from the biochar to the leached water and thus leaching of $\mathrm{PO}_{4}^{3-}-\mathrm{P}, \mathrm{NO}_{2}^{-}-\mathrm{N}$ and total $\mathrm{P}$ was increased in the soil with the finer texture. However, biochar retained water after heavy irrigation and leaching of $\mathrm{PO}_{4}^{3-} \mathrm{P}$ and total $\mathrm{P}$ was not increased on the coarser soil. Although pure biochar adsorbed $\mathrm{NH}_{4}^{+}-\mathrm{N}$ from nutrient solutions, $\mathrm{NH}_{4}^{+}-\mathrm{N}$ leaching from both soil types was generally not affected by biochar. Leaching of nitrate $\mathrm{NO}_{3}^{-}-\mathrm{N}$ and total $\mathrm{N}$ was decreased on both soils due to retention by the biochar.
\end{abstract}

Key words: pyrogenic carbon, litter bag, runoff, moisture, nitrogen, phosphorus

\section{Introduction}

Biochar addition may affect cycling of carbon $(C)$, nitrogen $(N)$, phosphorus $(P)$ and other nutrients in soils in many ways. The impacts on conditions and processes in the soil result from the biochar properties such as high specific surface area and porosity, low bulk density, alkaline $\mathrm{pH}$, high C:N ratio, low decomposability and diverse functional groups on the surface (e.g. Laird 2008, Mukherjee et al. 2011). However, the impacts of biochar addition vary across soil types, crops, biochar types and soil conditions (e.g. Gao and DeLuca 2016, Saarnio 2016, Glaser and Lehr 2019), as biochar is not a standard product and conditions in agricultural soils vary greatly both spatially and temporally across the globe. As the majority of current studies have concentrated on tropical, subtropical and temperate soils, there is a need for studies in boreal and arctic soils.

We selected two common soil types from the boreal region for the laboratory experiments; a sandy till and a medium fine sand, which differ in soil texture, $\mathrm{C}$ content and some of the nutrients. The aim was to study whether our chosen biochar could be used to decrease nutrient leaching from agricultural soils in the cooler temperatures prevalent in the non-vegetated period. We used biochar made from typical surplus material for the region: forestry residues. The biochar had a rather high specific surface area $\left(210 \mathrm{~m}^{2} \mathrm{~g}^{-1}\right), \mathrm{C}: \mathrm{N}$ ratio (499) and $\mathrm{pH}$ (10.9). These properties were expected to increase $\mathrm{pH}$ values and the retention of water, nutrients and organic compounds, and thus enhance nutrient availability in the soil (cf. Novak et al. 2009, Yao et al. 2012, Abel et al. 2013). In contrast, high $\mathrm{C}$ additions ( $5 \%$ of soil volume) without fertilization and with a high specific surface area of biochar were expected to retard decomposition processes due to $\mathrm{N}$ limitation ( $\mathrm{N}$ adsorption to biochar, $\mathrm{N}$ immobilization during the decomposition of labile fraction of biochar, unfertilized) and the adsorption of organic material (Zimmerman et al. 2011, Saarnio 2016, Kerré et al. 2017). Thus, we hypothesised that biochar addition 1) decreases nutrient $(N, P)$ leaching, especially from soils with low organic matter content, 2) decreases the decomposition rate of new organic litter (just added in soil) and 3 ) increases soil moisture content albeit with a smaller increase in soils with finer texture and better initial water holding capacity. We hypothesise that these changes would lead to decreased agricultural nutrient loading to watercourses during the non-vegetated phases of the field.

\section{Material and methods}

\section{Sorption and desorption of nutrients by biochar}

Six basins (diameter $31.5 \mathrm{~cm}$, depth $12 \mathrm{~cm}$ ) were equipped with geotextile (Lektex, JM Spunbond, Johns Manville Europe $\mathrm{GmbH}$, Germany), and a tube at the bottom to facilitate the sampling of water flowing through the ba$\sin$. An addition of $77.93 \mathrm{~g}$ of biochar, which corresponds to 10 tonnes of biochar per hectare, was added to the 


\section{AGRICULTURAL AND FOOD SCIENCE}

basins (hereafter referred to as pure biochar). Our biochar was produced from spruce chips at $400-450{ }^{\circ} \mathrm{C}$ using slow pyrolysis (for more details see Saarnio et al. 2013). Deionised water (2.25 I) was added to all basins and the amount of percolated water was measured and the concentrations of ammonium $\left(\mathrm{NH}_{4}^{+}-\mathrm{N}\right)$, nitrite $\left(\mathrm{NO}_{2}{ }^{-}-\mathrm{N}\right)$, nitrate + nitrite $\left(\mathrm{NO}_{3}{ }^{-}+\mathrm{NO}_{2}^{-}-\mathrm{N}\right)$, total $\mathrm{N}$, phosphate $\left(\mathrm{PO}_{4}^{3-}-\mathrm{P}\right)$ and total $\mathrm{P}$ and $\mathrm{pH}$ were determined from the percolated waters. Nutrients were analyzed spectrophotometrically using the following instruments (and standards); PharmaSpec UV-1700, Shimadzu, Japan for $\mathrm{NH}_{4}^{+}-\mathrm{N}$ (SFS 3032), QuickChem 8000, Lachat Instruments, USA for $\mathrm{NO}_{2}^{-}-\mathrm{N}(\mathrm{SFS} 3029), \mathrm{NO}_{2}{ }^{-}+\mathrm{NO}_{3}^{-}-\mathrm{N}$ (SFS 3030) and total N (SFS 3030) and UV/VIS Spectrometer Lambda 12, PerkinElmer, USA for $\mathrm{PO}_{4}{ }^{3-}-\mathrm{P}$ (SFS 3025) and total P (SFS 3026). The same procedure was repeated four times over an eight week period in order to see how much nutrients were released from the biochar (Fig. 1, leaching occasions 1-4). In order to test the ability of the biochar to adsorb nutrients from the percolating water, two water solutions with known nutrient contents and $\mathrm{pH}$ were prepared and added (2.25 I / basin) to the pure biochar basins on the next two leaching occasions (leaching occasions 5-6). Finally, deionized water was added (2.25 I) to all basins in order to see the rate of nutrient leaching after the possible nutrient retention during the exposure to nutrient solutions (leaching occasion 7).

\section{Soil and biochar preparation}

Two soils were collected for the experiments (Table 1): a sandy till (Dystric Arenosols according to WRB 2014 soil classification in Lilja et al. 2017) from an abandoned field in October 2009 (Mulo, Finland, 62 $31^{\prime} \mathrm{N}, 2^{\circ} 50^{\prime} \mathrm{E}$ ) and a medium fine sand (Endoleyic Podzols according to WRB 2014 soil classification in Lilja et al. 2017) from an actively cultivated field in May 2011 (Viikki, Finland, 60¹3'42" N, 25²' 34" E). For both soils, loss of ignition was determined by heating the samples at $550^{\circ} \mathrm{C}$ for $2 \mathrm{~h}$ (standard SFS 3008), total organic carbon (TOC) with an N/C analyzer (Analytik Jena N/C 2100, Jena, Germany) after removal of inorganic $\mathrm{C}$ with $1 \mathrm{M} \mathrm{H}_{3} \mathrm{PO}_{4}$, and $\mathrm{N}$ content with the Kjeldahl method (Vapodest 30, Gerhardt, Germany; Coombs et al. 1987). All other soil characteristics were analyzed with standard methods by the accredited laboratory of Eurofins Viljavuuspalvelu Oy (Eurofins Viljavuuspalvelu Oy 2020).

Table 1. Characteristics of the soils used in this study. Fertility classes from lowest to highest nutrient content: poor, rather poor, tolerable, satisfactory, good, high and very high (Eurofins Viljavuuspalvelu Oy 2020)

\begin{tabular}{|c|c|c|}
\hline Element & Sandy till & Medium fine sand \\
\hline Loss of ignition, \% & 8 & 6 \\
\hline Total Organic Carbon, \% & 3.74 & 1.05 \\
\hline Nitrogen, \% & 0.25 & 0.19 \\
\hline $\begin{array}{l}\text { Phosphorus, } \mathrm{mg}^{-1} \\
\text { (plant available) }\end{array}$ & $\begin{array}{c}6.8 \\
\text { tolerable }\end{array}$ & $\begin{array}{c}18 \\
\text { good }\end{array}$ \\
\hline $\begin{array}{l}\text { Calcium, } \mathrm{mg} \mathrm{l}^{-1} \\
\text { (plant available) }\end{array}$ & $\begin{array}{c}1600 \\
\text { satisfactory }\end{array}$ & $\begin{array}{c}1000 \\
\text { tolerable }\end{array}$ \\
\hline $\begin{array}{l}\text { Potassium, } \mathrm{mg} \mathrm{l}^{-1} \\
\text { (plant available) }\end{array}$ & $\begin{array}{c}140 \\
\text { satisfactory }\end{array}$ & $\begin{array}{c}79 \\
\text { tolerable }\end{array}$ \\
\hline $\begin{array}{l}\text { Magnesium, } \mathrm{mg} \mathrm{l}^{-1} \\
\text { (plant available) }\end{array}$ & $\begin{array}{c}100 \\
\text { tolerable }\end{array}$ & $\begin{array}{c}100 \\
\text { tolerable }\end{array}$ \\
\hline $\begin{array}{l}\text { Sulphur, mg l-1 } \\
\text { (plant available) }\end{array}$ & $\begin{array}{l}22.2 \\
\text { good }\end{array}$ & $\begin{array}{l}5.6 \\
\text { rather poor }\end{array}$ \\
\hline \multicolumn{3}{|l|}{ Fraction, \% } \\
\hline gravel (2-20 mm) & 11 & 0 \\
\hline coarse sand $(0.2-2 \mathrm{~mm})$ & 39 & 19 \\
\hline fine sand $(0.02-0.2 \mathrm{~mm})$ & 32 & 72 \\
\hline silt $(0.002-0.02 \mathrm{~mm})$ & 11 & 2 \\
\hline clay $(<0.002 \mathrm{~mm})$ & 7 & 7 \\
\hline Conductivity value, $10 \times \mathrm{mS} \mathrm{cm}^{-1}$ & 3.1 & 0.7 \\
\hline $\mathrm{pH}\left(\mathrm{H}_{2} \mathrm{O}\right)$ & 5.8 & 5.9 \\
\hline CEC, meq / $100 \mathrm{~g}$ & 11.6 & 7.7 \\
\hline $\mathrm{C}: \mathrm{N}$ ratio & 15 & 6 \\
\hline
\end{tabular}




\section{AGRICULTURAL AND FOOD SCIENCE}

S. Saarnio \& R. Kettunen (2020) 29: 287-296

The sandy till was sieved through a $7 \mathrm{~mm}$ sieve and the medium fine sand through a $3 \mathrm{~mm}$ sieve in order to remove bigger stones and organic remains. Six liters of soil were placed into each of the 12 basins equipped with geotextile. An addition of $77.93 \mathrm{~g}$ of biochar $\left(10 \mathrm{t} \mathrm{ha}^{-1}\right)$ was mixed into the soil of six basins. The remaining set of six basins acted as controls. The number of replicates for the medium fine sand experiment was five due to a limited amount of litter.

\section{Decomposition and leaching procedures}

Three litter bags ( $1 \mathrm{~mm}$ nylon mesh) were inserted into the soil at a depth of $3 \mathrm{~cm}$ during the filling of the basins. The first litter bag contained a $4 \times 10 \mathrm{~cm}$ piece of cellulose (Stora-Enso Packing, Enocell Oy, Finland) weighing c. $3 \mathrm{~g}$ (twice as heavy as grass due to a simpler composition and thus easier decomposability). The second litter bag contained $1.5 \mathrm{~g}$ of leaves and shoots of Phleum pratense grown in the same soil, and the third litter bag contained leaves and shoots of $P$. pratense grown in the same soil with a biochar addition (10 $\mathrm{t} \mathrm{ha} \mathrm{a}^{-1}$, for details see Saarnio et al. 2013, Niemi et al. 2015). The basins were kept at $15{ }^{\circ} \mathrm{C}$ for 7 or 13 weeks, at $5{ }^{\circ} \mathrm{C}$ for the next 6 or 9 weeks and at $15{ }^{\circ} \mathrm{C}$ for the last 6 or 9 weeks during the medium fine sand and sandy till experiments, respectively. The duration of the medium fine sand experiment (19 weeks) was shorter than the sandy till experiment ( 31 weeks) as the $P$. pratense litter contained five times more $\mathrm{N}$ in the medium fine sand experiment (Table 2 ) and was thus expected to totally decompose in 31 weeks. All basins were watered with the same amount of deionised water and the volumetric soil moisture content at the depth of 0-6 cm was measured with a Theta Probe type ML2 connected to a Theta Meter type HH1 (Delta-T Devices, Cambridge, England). At the end of the experiment, the litter bags were removed from the soils, washed with care and the dried litter remains were weighed.

Table 2. The $\mathrm{N}$ content (\%) of Phleum pratense leaves and shoots used in the litter bags. The biomass originated from earlier growth and gas exchange experiments conducted with the same soil and biochar types (for details see Saarnio et al. 2013, Niemi et al. 2015)

\begin{tabular}{|c|c|c|}
\hline \multirow{2}{*}{$\begin{array}{l}\text { Soil type (both in this experiment and earlier } \\
\text { growth and gas exchange experiments) }\end{array}$} & \multicolumn{2}{|c|}{$\begin{array}{l}\text { Treatments in the earlier growth experiments / litter bag number in this } \\
\text { experiment }\end{array}$} \\
\hline & Soil (control) /second litter bag & Soil + biochar $\left(10 \mathrm{t} \mathrm{ha}^{-1}\right) /$ third litter bag \\
\hline Sandy till & 0.87 & 0.81 \\
\hline Medium fine sand & 4.14 & 4.09 \\
\hline
\end{tabular}

The basins were saturated with deionised water (2-2.25 liters per basin) once during each of the three temperature periods in order to provide water samples for nutrient and $\mathrm{pH}$ analyses. After the water addition, three way stop cock at the end of short silicone hose connected to the bottom of the basin was opened and all water percolated through the soil was collected. Nutrient analyses for the first two water samplings from the sandy till experiment were carried out spectrophotometrically using the FIA-method for $\mathrm{PO}_{4}^{3-}-\mathrm{P}$, total $\mathrm{P}, \mathrm{NO}_{2}^{-}-\mathrm{N}, \mathrm{NO}_{2}^{-}+$ $\mathrm{NO}_{3}^{-}-\mathrm{N}$ and total $\mathrm{N}$ and the UV/VIS technique for $\mathrm{NH}_{4}^{+}-\mathrm{N}$ at the accredited laboratory of the Finnish Environment Institute. The nutrient analyses for the third water sampling from sandy till experiment and for all three water samplings from medium fine sand experiment were carried out at the Department of Biology, University of Eastern Finland using the standards and instruments mentioned above. The amount of leached water $(\mathrm{ml})$ and nutrient concentrations $\left(\mu \mathrm{g} \mathrm{I}^{-1}\right)$ were used to calculate the amount of leached nutrients during each sampling occasion. As the amount of leached water was not recorded during the second and third sampling occasions on the sandy till, the amount of water recorded from the first sampling was used to estimate the amount of leached nutrients on the second and third sampling occasions on that soil. On the medium fine sand, the amount of leached water was measured during all three samplings.

\section{Statistical analysis}

Differences in the concentrations and amounts of leached nutrients and in the soil moisture content between biochar treatments during the whole experiment were tested using a repeated measures analysis of variance. Differences in mass loss of litter, as well as the concentrations and leached amounts of $\mathrm{NH}_{4}^{+}-\mathrm{N}, \mathrm{NO}_{2}^{-}{ }^{-} \mathrm{N}, \mathrm{NO}_{3}^{-}-\mathrm{N}$, total $\mathrm{N}$, $\mathrm{PO}_{4}{ }^{3-}-\mathrm{P}$ and total $\mathrm{P}$ and soil moisture between treatments during the individual measuring days were tested using a t-test. Normality of the variables and equality of variances were tested using the Kolmogorov-Smirnov and Levene tests, respectively. Differences in the sums of leached nutrients between soil types, biochar treatments and their interactions were tested by analysis of variance. All tests were performed with IBM SPSS Statistics, version 19/21. 


\section{AGRICULTURAL AND FOOD SCIENCE}

\section{Results}

\section{Nutrients}

The amounts of $\mathrm{PO}_{4}^{3-}-\mathrm{P}\left(127-366 \mu \mathrm{g} \mathrm{I}^{-1}\right)$ and total $\mathrm{P}\left(128-381 \mu \mathrm{g} \mathrm{I}^{-1}\right)$ leached from the pure biochar were very high (Fig. 1), particularly in comparison to the amounts leached from biochar mixed in the soil (sandy till: 0-71 $\mu \mathrm{g} \mathrm{I}^{-1}$ and 14-166 $\mu \mathrm{g} \mathrm{I}^{-1}$, respectively, Table 3 and medium fine sand: 36-67 $\mu \mathrm{g} \mathrm{I}^{-1}$ and 42-85 $\mu \mathrm{g} \mathrm{I}^{-1}$, respectively, Table 4). In contrast, the amounts of $\mathrm{NH}_{4}^{+}-\mathrm{N}\left(1-6 \mu \mathrm{g} \mathrm{l}^{-1}\right), \mathrm{NO}_{3}^{-}-\mathrm{N}\left(3-14 \mu \mathrm{gl}^{-1}\right)$ and total $\mathrm{N}\left(37-79 \mu \mathrm{g} \mathrm{l}^{-1}\right)$ leached from the pure biochar were very low. The pure biochar significantly adsorbed $\mathrm{NH}_{4}^{+}-\mathrm{N}(9-47 \%$ of the applied amount), $\mathrm{NO}_{3}-\mathrm{N}(5-31 \%)$ and total $\mathrm{N}(5-34 \%)$ when the nutrient solutions were allowed to percolate through the biochar, whereas leaching of excess $\mathrm{NO}_{2}^{-}-\mathrm{N}, \mathrm{PO}_{4}^{3-} \mathrm{P}$ and total $\mathrm{P}$ from the pure biochar was evident (leaching occasions 5-6). Leaching of $\mathrm{NO}_{2}^{-}$and $\mathrm{PO}_{4}^{3-}$ from the biochar was higher under lower $\mathrm{pH}$ levels (3.69 for stronger nutrient solution before contact to biochar) than under higher $\mathrm{pH}$ (cf. 5.65 for milder solution before contact to biochar). The percolation of nutrient solutions through the biochar increased the $\mathrm{pH}$ to a neutral level (on average 7.46 for both solutions after percolation through biochar). The last addition of deionized water (leaching occasion 7) showed that the majority of $\mathrm{NO}_{3}^{-}-\mathrm{N}(96 \%)$ and total $\mathrm{N}(86 \%)$ adsorbed from the previous nutrient solutions, was released to the pure water but leaching of $\mathrm{NH}_{4}{ }^{+}-\mathrm{N}, \mathrm{NO}_{2}-\mathrm{N}, \mathrm{PO}_{4}{ }^{3-}-\mathrm{P}$ and total $\mathrm{P}$ remained at the same level as before the addition of nutrient solutions.
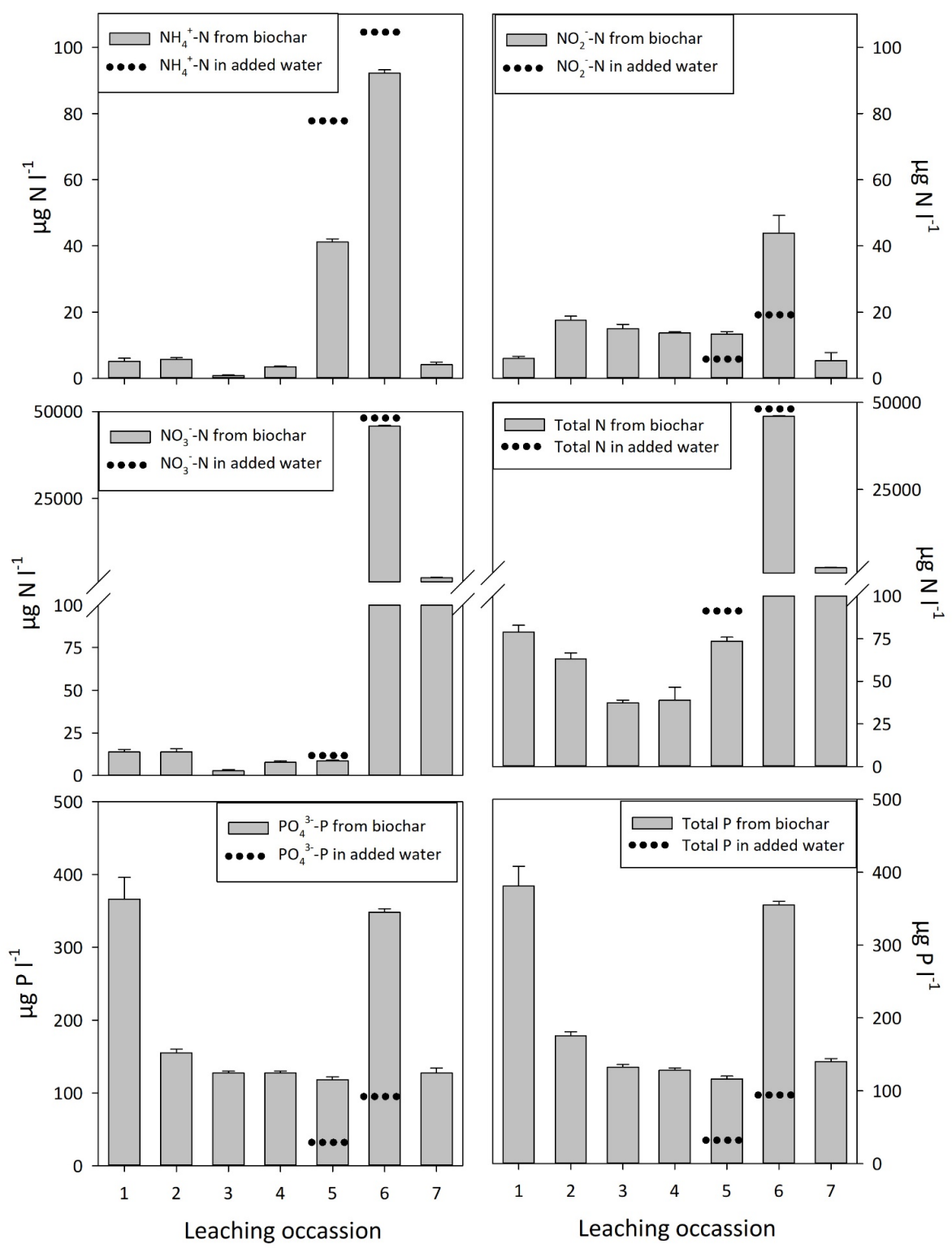

Fig. 1. Mean (+ standard error of mean) nutrient concentrations in water percolated through pure biochar during seven leaching occasions. Horizontal lines indicate the nutrient content in the added water. $\mathrm{n}=6$ 


\section{AGRICULTURAL AND FOOD SCIENCE}

S. Saarnio \& R. Kettunen (2020) 29: 287-296

The repeated measures analyses showed that there were significant differences between measuring days and biochar treatments for almost all nutrients in both soils (Tables 3 and 4). Biochar addition decreased the concentrations of $\mathrm{NO}_{3}-\mathrm{N}$ and total $\mathrm{N}$ but increased the concentrations of $\mathrm{PO}_{4}{ }^{3-}-\mathrm{P}$ and total $\mathrm{P}$ and, on occasion, the concentrations of $\mathrm{NH}_{4}^{+}-\mathrm{N}$ and $\mathrm{NO}_{2}^{-}-\mathrm{N}$ in the outflowing water on both soils. Biochar also increased pH levels in the outflowing water from both soils.

Table 3. Mean ( \pm standard error of mean) concentration in the leached water and the amount of leached nutrients during three sampling occasions on the sandy till soil. Small letters indicate significant $(p<0.05)$ or in parenthesis indicative (i.e. $0.05 \leq p<0.10)$ differences between biochar treatments during the experimental day in question. RM = repeated measures analysis, significant factors mentioned: $\mathrm{T}=$ time, $\mathrm{B}=$ biochar, $\mathrm{T} \times \mathrm{B}$ interaction of time and biochar, $\mathrm{n}=6$

\begin{tabular}{|c|c|c|c|c|c|c|c|}
\hline & \multicolumn{2}{|c|}{ Experimental day 31} & \multicolumn{2}{|c|}{ Experimental day 100} & \multicolumn{2}{|c|}{ Experimental day 218} & \multirow[b]{2}{*}{ RM } \\
\hline & Biochar & Control & Biochar & Control & Biochar & Control & \\
\hline $\mathrm{pH}$ & $6.24 \pm 0.05^{\mathrm{a}}$ & $6.05 \pm 0.03^{b}$ & $6.01 \pm 0.04$ & $5.95 \pm 0.02$ & - & - & $\mathrm{T}, \mathrm{B}$ \\
\hline \multicolumn{8}{|c|}{ Concentration } \\
\hline $\mathrm{PO}_{4}^{3-}-\mathrm{P}, \mu \mathrm{g}^{-1}$ & $159 \pm 19^{a}$ & $88 \pm 10^{b}$ & $41 \pm 3^{(a)}$ & $30 \pm 4^{(b)}$ & $37 \pm 3$ & $37 \pm 6$ & $\mathrm{~T}, \mathrm{~T} \times \mathrm{B}, \mathrm{B}$ \\
\hline total $P,\left.\mu g\right|^{-1}$ & $448 \pm 51^{\mathrm{a}}$ & $282 \pm 25^{b}$ & $122 \pm 9$ & $104 \pm 15$ & $134 \pm 11$ & $120 \pm 9$ & $\mathrm{~T}, \mathrm{~T} \times \mathrm{B}, \mathrm{B}$ \\
\hline $\mathrm{NH}_{4}^{+}-\mathrm{N}, \mu \mathrm{gl}^{-1}$ & $3133 \pm 459^{\mathrm{a}}$ & $1192 \pm 393^{b}$ & $7.2 \pm 1.1$ & $9.0 \pm 3.2$ & $13.9 \pm 3.1$ & $9.4 \pm 1.8$ & $T, T \times B, B$ \\
\hline $\mathrm{NO}_{2}^{-}-\mathrm{N}, \mu \mathrm{gl}^{-1}$ & $134.7 \pm 13.1^{\mathrm{a}}$ & $24.2 \pm 6.1^{b}$ & $1.5 \pm 0.2$ & $2.2 \pm 0.5$ & - & - & $T, T \times B, B$ \\
\hline $\mathrm{NO}_{3}^{-}-\mathrm{N}, \mathrm{mg} \mathrm{l}^{-1}$ & $35.7 \pm 2.0$ & $40.7 \pm 6.6$ & $50 \pm 5$ & $52 \pm 5$ & $* 48 \pm 5^{a}$ & $* 73 \pm 3^{b}$ & $\mathrm{~T}$ \\
\hline total $\mathrm{N}, \mathrm{mg} \mathrm{l}^{-1}$ & $42.0 \pm 2.3$ & $44.5 \pm 7.3$ & $54 \pm 5$ & $56 \pm 5$ & $52 \pm 5^{a}$ & $77 \pm 3^{b}$ & $T, T \times B, B$ \\
\hline \multicolumn{8}{|c|}{ Leached } \\
\hline Water, ml & $780 \pm 48^{\mathrm{a}}$ & $1006 \pm 39^{b}$ & $* *$ & $* *$ & $* *$ & $* *$ & \\
\hline $\mathrm{PO}_{4}^{3-}-\mathrm{P}, \mu \mathrm{g}$ & $123 \pm 16$ & $89 \pm 13$ & $32 \pm 1$ & $30 \pm 3$ & $29 \pm 3$ & $37 \pm 5$ & $\mathrm{~T}$ \\
\hline total $P, \mu g$ & $349 \pm 48$ & $285 \pm 33$ & $93 \pm 4$ & $102 \pm 12$ & $103 \pm 6$ & $120 \pm 8$ & $\mathrm{~T}$ \\
\hline $\mathrm{NH}_{4}^{+}-\mathrm{N}, \mu \mathrm{g}$ & $2420 \pm 337^{a}$ & $1170 \pm 363^{b}$ & $5.7 \pm 1.0$ & $8.7 \pm 2.7$ & $10.3 \pm 1.9$ & $9.7 \pm 2.1$ & $\mathrm{~T}, \mathrm{~T} \times \mathrm{B}, \mathrm{B}$ \\
\hline $\mathrm{NO}_{2}^{-}-\mathrm{N}, \mu \mathrm{g}$ & $101.9 \pm 4.5^{\mathrm{a}}$ & $23.6 \pm 6.1^{b}$ & $1.2 \pm 0.2$ & $2.2 \pm 0.5$ & - & - & $\mathrm{T}, \mathrm{T} \times \mathrm{B}, \mathrm{B}$ \\
\hline $\mathrm{NO}_{3}^{-}-\mathrm{N}, \mathrm{mg}$ & $27.8 \pm 2.4$ & $40.7 \pm 6.9$ & $38.6 \pm 3.2^{\mathrm{a}}$ & $51.0 \pm 3.3^{b}$ & $* 37.3 \pm 3.4^{\mathrm{a}}$ & $* 73.9 \pm 5.3^{b}$ & $\mathrm{~T}, \mathrm{~B}$ \\
\hline total $\mathrm{N}, \mathrm{mg}$ & $32.7 \pm 2.7$ & $44.6 \pm 7.6$ & $41.1 \pm 3.1^{\mathrm{a}}$ & $55.2 \pm 3.4^{b}$ & $40.0 \pm 3.6^{a}$ & $77.6 \pm 5.6^{b}$ & $\mathrm{~T}, \mathrm{~B}$ \\
\hline
\end{tabular}

${ }^{*}=$ includes also nitrite- $\mathrm{N} ;{ }^{* *}=$ water leaching was assumed to be the same as during the first sampling in calculations of nutrient leaching during the second and third sampling occasions

Table 4. Mean ( \pm standard error of mean) concentration in the leached water and the amount of leached nutrients during three sampling occasions on the medium fine sand soil. Small letters indicate significant $(p<0.05)$ or in parenthesis indicative (i.e. 0.05 $\leq p<0.10$ ) differences between biochar treatments during the experimental day in question. RM = repeated measures analysis, significant factors mentioned, $\mathrm{T}=$ time, $\mathrm{B}=$ biochar, $\mathrm{T} \times \mathrm{B}$ interaction of time and biochar, $\mathrm{n}=5$

\begin{tabular}{|c|c|c|c|c|c|c|c|}
\hline & \multicolumn{2}{|c|}{ Experimental day 46} & \multicolumn{2}{|c|}{ Experimental day 88} & \multicolumn{2}{|c|}{ Experimental day 130} & \multirow[b]{2}{*}{ RM } \\
\hline & Biochar & Control & Biochar & Control & Biochar & Control & \\
\hline \multirow[t]{2}{*}{$\mathrm{pH}$} & $5.92 \pm 0.02^{a}$ & $5.56 \pm 0.02^{b}$ & $6.28 \pm 0.04^{a}$ & $5.66 \pm 0.02^{b}$ & $6.14 \pm 0.07^{a}$ & $5.62 \pm 0.04^{b}$ & $\mathrm{~T}, \mathrm{~B}, \mathrm{~T} \times \mathrm{B}$ \\
\hline & & & Concentration & & & & \\
\hline $\mathrm{PO}_{4}^{3-}-\mathrm{P}, \mu \mathrm{gl}^{-1}$ & $243 \pm 16^{a}$ & $186 \pm 10^{b}$ & $209 \pm 22^{a}$ & $142 \pm 9^{b}$ & $194 \pm 17^{(a)}$ & $158 \pm 4^{(b)}$ & $\mathrm{T}, \mathrm{B}$ \\
\hline total $P,\left.\mu g\right|^{-1}$ & $336 \pm 31^{(a)}$ & $254 \pm 10^{(b)}$ & $271 \pm 30^{a}$ & $186 \pm 12^{b}$ & $244 \pm 19^{(a)}$ & $202 \pm 4^{(b)}$ & $\mathrm{T}, \mathrm{B}$ \\
\hline $\mathrm{NH}_{4}^{+}-\mathrm{N}, \mu \mathrm{gl}^{-1}$ & $15.9 \pm 3.4$ & $25.8 \pm 6.5$ & $5.2 \pm 1.5$ & $22.8 \pm 13.7$ & $4.1 \pm 0.7$ & $5.4 \pm 0.7$ & \\
\hline $\mathrm{NO}_{2}^{-}-\mathrm{N}, \mu \mathrm{g} \mathrm{l^{-1 }}$ & $23.8 \pm 4.9^{(a)}$ & $10.6 \pm 1.5^{(b)}$ & $21.3 \pm 4.1^{(a)}$ & $10.3 \pm 1.5^{(b)}$ & $11.3 \pm 1.4^{(a)}$ & $7.7 \pm 0.4^{(b)}$ & $\mathrm{T}, \mathrm{B}$ \\
\hline $\mathrm{NO}_{3}^{-}-\mathrm{N}, \mathrm{mg} \mathrm{l}^{-1}$ & $12.8 \pm 0.7^{a}$ & $39.5 \pm 2.2^{b}$ & $8.0 \pm 0.8^{a}$ & $39.6 \pm 2.3^{b}$ & $4.9 \pm 1.9^{a}$ & $36.6 \pm 1.8^{b}$ & $\mathrm{~T}, \mathrm{~B}$ \\
\hline \multirow[t]{2}{*}{ total $\mathrm{N}, \mathrm{mg} \mathrm{l}^{-1}$} & $14.0 \pm 0.6^{a}$ & $40.8 \pm 2.2^{b}$ & $8.6 \pm 0.8^{a}$ & $42.2 \pm 2.5^{b}$ & $5.7 \pm 2.1^{\mathrm{a}}$ & $39.0 \pm 2.0^{b}$ & B \\
\hline & & & Leached & & & & \\
\hline Water, ml & $1156 \pm 89$ & $1108 \pm 34$ & $1319 \pm 43$ & $1294 \pm 27$ & $1216 \pm 60$ & $1147 \pm 18$ & $\mathrm{~T}, \mathrm{~B}$ \\
\hline $\mathrm{PO}_{4}{ }^{3-}-\mathrm{P}, \mu \mathrm{g}$ & $276 \pm 12^{\mathrm{a}}$ & $207 \pm 17^{b}$ & $273 \pm 22^{\mathrm{a}}$ & $183 \pm 9^{b}$ & $234 \pm 20^{\mathrm{a}}$ & $181 \pm 5^{b}$ & B \\
\hline total $P, \mu g$ & $380 \pm 23^{a}$ & $283 \pm 19^{b}$ & $354 \pm 31^{a}$ & $240 \pm 12^{b}$ & $295 \pm 23^{a}$ & $232 \pm 4^{b}$ & $\mathrm{~T}, \mathrm{~B}$ \\
\hline $\mathrm{NH}_{4}^{+}-\mathrm{N}, \mu \mathrm{g}$ & $17.4 \pm 2.7$ & $29.2 \pm 8.4$ & $6.7 \pm 1.7$ & $30.7 \pm 19.2$ & $4.9 \pm 0.8$ & $6.2 \pm 0.9$ & \\
\hline $\mathrm{NO}_{2}^{-}-\mathrm{N}, \mu \mathrm{g}$ & $26.2 \pm 4.5^{a}$ & $11.9 \pm 1.8^{b}$ & $27.7 \pm 4.8^{a}$ & $13.3 \pm 1.8^{\mathrm{b}}$ & $13.9 \pm 2.2^{(a)}$ & $8.9 \pm 0.4^{(b)}$ & $\mathrm{T}, \mathrm{B}$ \\
\hline $\mathrm{NO}_{3}^{-}-\mathrm{N}, \mathrm{mg}$ & $14.9 \pm 1.8^{a}$ & $43.8 \pm 3.3^{b}$ & $10.6 \pm 1.3^{a}$ & $51.5 \pm 3.8^{b}$ & $5.6 \pm 2.0^{a}$ & $41.9 \pm 1.7^{b}$ & $\mathrm{~T}, \mathrm{~B}$ \\
\hline total $\mathrm{N}, \mathrm{mg}$ & $16.3 \pm 1.8^{\mathrm{a}}$ & $45.3 \pm 3.3^{b}$ & $11.4 \pm 1.2^{\mathrm{a}}$ & $54.8 \pm 4.0^{b}$ & $6.6 \pm 2.2^{\mathrm{a}}$ & $44.6 \pm 2.0^{b}$ & B \\
\hline
\end{tabular}




\section{AGRICULTURAL AND FOOD SCIENCE}

Soil type, biochar treatment and their interaction were statistically significant for all studied variables (Table 5). More $\mathrm{P}$ and less $\mathrm{N}$ were leached from the medium fine sand than those from the sandy till reflecting the original $\mathrm{P}$ and $\mathrm{N}$ content of those soils (Table 1). In total, biochar addition increased the leaching of $\mathrm{P}$ but decreased leaching of $\mathrm{N}$, although there were some discrepancies between soil types and nutrient forms.

Table 5. Mean ( \pm standard error of mean) amount of leached nutrients during the whole experiment. Soil type (S), biochar treatment (B) and their interaction $(S \times B)$ were statistically significant in the case of all nutrient forms.

\begin{tabular}{lcccccc}
\hline & \multicolumn{2}{c}{ Sandy till } & \multicolumn{2}{c}{ Medium fine sand } & \multicolumn{2}{c}{ Significance } \\
\hline & Biochar & Control & Biochar & Control & Soil & Biochar \\
$\mathrm{PO}_{4}{ }^{3-}-\mathrm{P}, \mu \mathrm{g}$ & $183 \pm 19$ & $156 \pm 13$ & $783 \pm 15$ & $572 \pm 24$ & $<0.0005$ & $<0.0005$ \\
total P, $\mu \mathrm{g}$ & $545 \pm 51$ & $508 \pm 29$ & $1029 \pm 38$ & $756 \pm 29$ & $<0.0005$ & 0.001 \\
$\mathrm{NH}_{4}{ }^{+}-\mathrm{N}, \mu \mathrm{g}$ & $2436 \pm 337$ & $1188 \pm 362$ & $29 \pm 4$ & $66 \pm 20$ & $<0.0005$ & 0.040 \\
$\mathrm{NO}_{2}^{-}-\mathrm{N}, \mu \mathrm{g}$ & $103 \pm 4$ & $26 \pm 6$ & $68 \pm 10$ & $34 \pm 4$ & 0.041 & $<0.0005$ \\
$\mathrm{NO}_{3}-\mathrm{N}, \mathrm{mg}$ & $104 \pm 6$ & $166 \pm 6$ & $31 \pm 4$ & $137 \pm 2$ & $<0.0005$ & $<0.0005$ \\
total N, mg & $114 \pm 6$ & $177 \pm 7$ & $34 \pm 4$ & $145 \pm 2$ & $<0.0005$ & $<0.0005$ \\
\hline
\end{tabular}

\section{Litter}

On the sandy till, mass loss of cellulose was higher than that of the shoots of $P$. pratense (Fig. 2) and the decomposition rate was over twice as high for cellulose $\left(12-13 \mathrm{mg} \mathrm{d}^{-1}\right)$ than that for $P$. pratense $\left(5 \mathrm{mg} \mathrm{d}^{-1}\right)$. Biochar addition did not affect the decomposition rate of the $\mathrm{N}$-poor shoots of $P$. pratense or pure cellulose. On the medium fine sand, the decomposition rate was almost the same for both litter types (8-9 $\mathrm{mg} \mathrm{d}^{-1}$ ) and biochar addition significantly increased the mass loss of N-rich $P$. pratense litter.
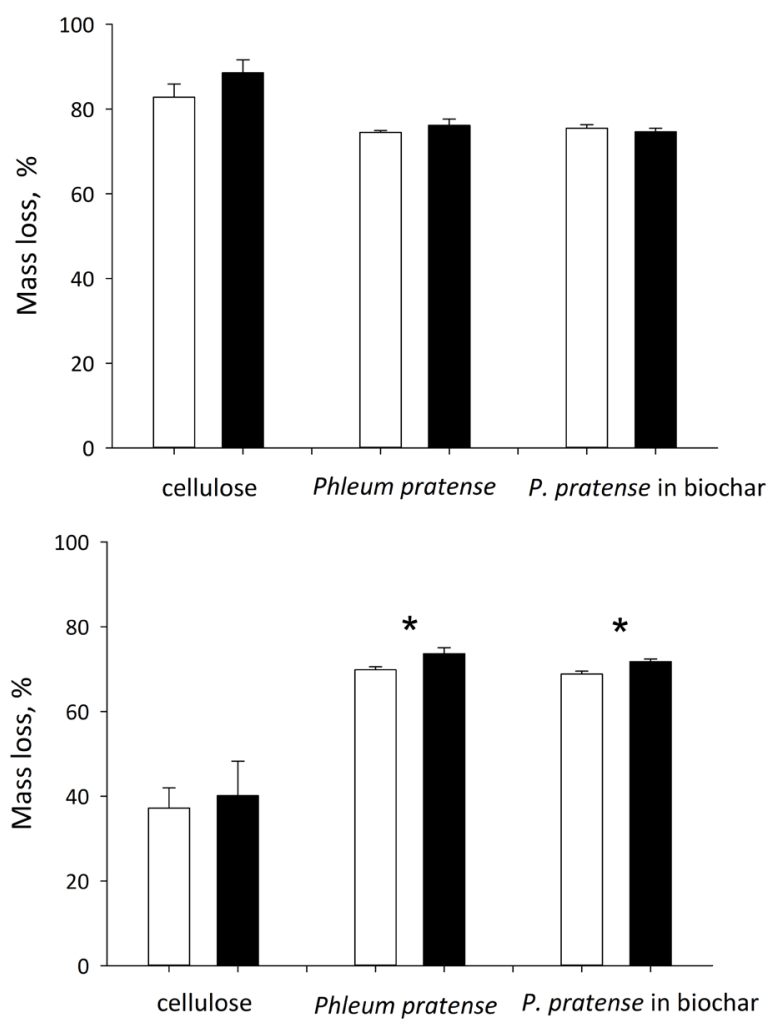

Fig. 2. Mean (+ standard error of mean) mass loss of cellulose, Phleum pratense shoots grown on the control soil and $P$. pratense shoots grown on biochar amended sandy till (upper, $n=6$ ) and medium fine sand soils (lower, $n=5$ ). White bars indicate control soil and black bars indicate biochar amended soil. ${ }^{*}=$ statistically significant difference $(p<0.05)$ between biochar treatments 


\section{AGRICULTURAL AND FOOD SCIENCE}

\section{Water}

Despite identical irrigation regimes, soil moisture content at the depth of $0-6 \mathrm{~cm}$ (\% of the volume) varied between treatments during the experiment on both soils (Fig. 3). After the heavy irrigation occasions (needed for water sampling for nutrient analyses), biochar improved water retention, significantly increasing the surface moisture content in both the sandy till and the medium fine sand for 1-2 weeks. However, the amount of added water remaining in the soil after water sampling was significantly higher in the biochar treatment than in the control, only on the sandy till (first sampling $p=0.004$, Table 3). During the light irrigation occasions (used to compensate for evaporated water), soil surface moisture in the biochar-amended soils did not differ or was, on occasion, even lower than that in the control soils. Furthermore, in the case of the pure biochar experiment, 10-20\% of the added water was absorbed by the biochar.
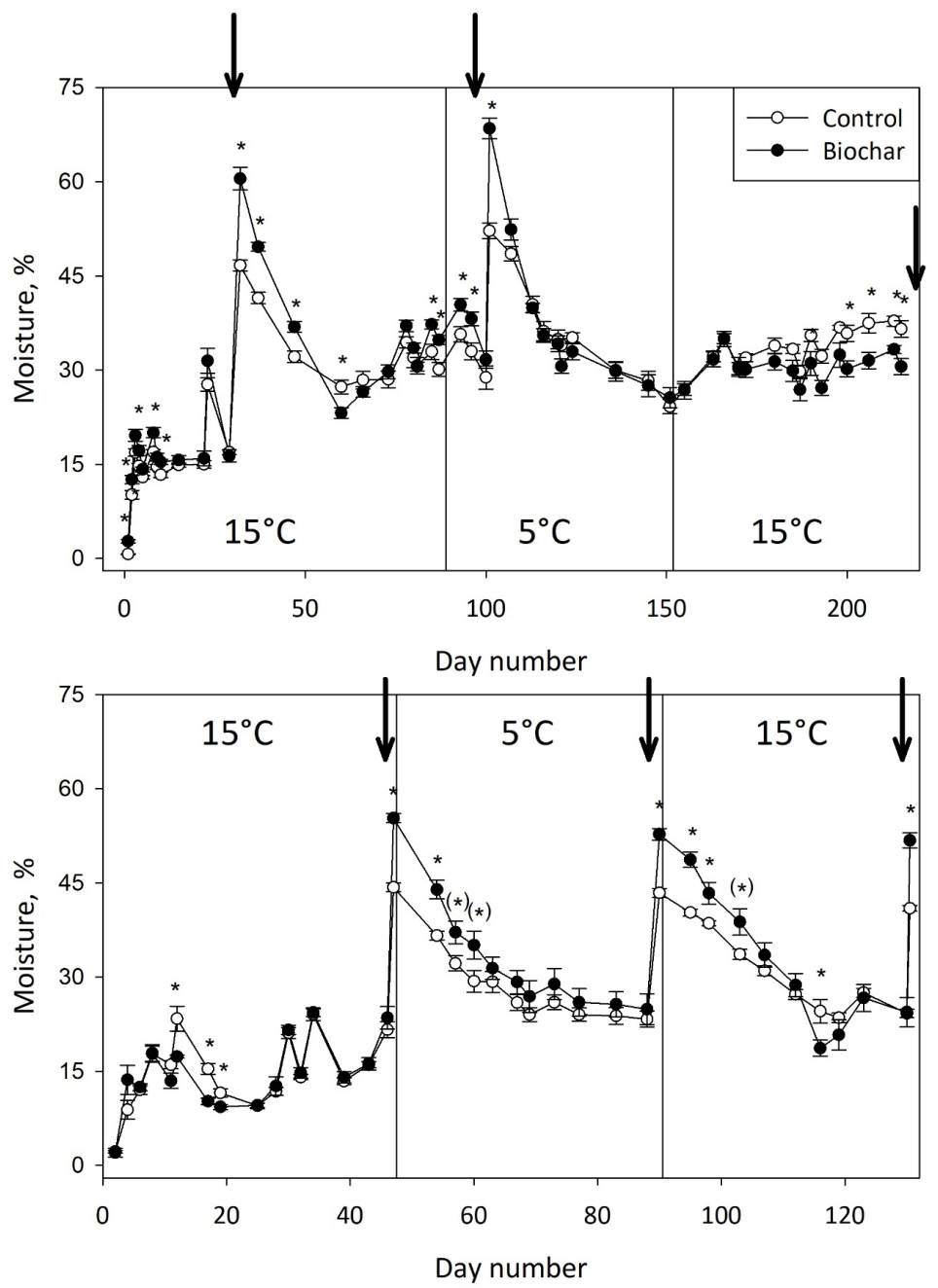

Fig. 3. Mean ( \pm standard error of mean) volumetric soil moisture content at the depth of $0-6 \mathrm{~cm}$ on sandy till (upper, $\mathrm{n}=6$ ) and medium fine sand (lower, $\mathrm{n}=5$ ) experiments. ${ }^{*}=$ statistically significant difference $(p<0.05)$ between biochar treatments, $\left({ }^{*}\right)$ indicative difference $(0.05 \leq p \leq 0.10)$ between treatments. Arrows indicate the moments of water sampling.

\section{Discussion}

\section{Biochar increases phosphorus leaching but decreases nitrogen leaching}

The presence of biochar in the soil increased the concentrations of $\mathrm{PO}_{4}^{3}-\mathrm{P}$, total $\mathrm{P}$ and $\mathrm{NO}_{2}-\mathrm{N}$ in the outflowing water on both soils, but the effect was stronger on the medium fine sand; the soil with the higher $\mathrm{P}$ content. It is likely that the excess $\mathrm{PO}_{4}{ }^{3-}$, total $\mathrm{P}$ and $\mathrm{NO}_{2}$ - originated from the fresh biochar itself. The mixing of biochar in the soil, however, considerably diminished the amounts of leached $\mathrm{PO}_{4}{ }^{3-}$, total $\mathrm{P}$ and $\mathrm{NO}_{2}$ - compared to the pure biochar (cf. $\mathrm{PO}_{4}^{3-}$ in Parvage et al. 2013). The release was most pronounced during the first irrigation occasion and 


\section{AGRICULTURAL AND FOOD SCIENCE}

S. Saarnio \& R. Kettunen (2020) 29: 287-296

faded or stopped during the later water samplings on both soil types (cf. $\mathrm{PO}_{4}{ }^{3-}$ in Saarnio et al. 2018) and on the pure biochar (cf. $\mathrm{PO}_{4}^{3-}$ in Hale et al. 2013). In the case of biochars with high ash contents (our biochar contained $31 \%$ ash), the released P probably originates from ash (Wang et al. 2012, Mukherjee and Zimmerman 2013) but P release from biochar with low ash content (4\%) has also been observed (Angst and Sohi 2013). According the meta-analysis of Glaser and Lehr (2019), wood-derived biochars are poor P fertilizers in general. Some of the biochar induced $\mathrm{PO}_{4}^{3-}$ leaching may also have originated from soil as our alkaline biochar has probably increased soil $\mathrm{pH}$ and thus the solubility of $\mathrm{P}$ (significant biochar induced increase in the $\mathrm{pH}$ of the percolated water was observed on the medium fine sand). Independent of ash content, some biochars adsorb $\mathrm{PO}_{4}{ }^{3-}$ and the adsorption capacity is probably related to the amount of calcium carbonate, metal ions and basic functional groups on the surface of biochars (Yao et al. 2013, Wang et al. 2015, Zhang et al. 2016). These variable results indicate that further studies are needed to verify the $\mathrm{P}$ release/retention mechanisms of different biochars.

Our biochar significantly adsorbed $\mathrm{N}$ both in the form of cations $\left(\mathrm{NH}_{4}^{+}\right)$and anions $\left(\mathrm{NO}_{3}{ }^{-}\right)$at both low and high concentrations, and when mixed in the soil, decreased $\mathrm{NO}_{3}^{-}-\mathrm{N}$ and total $\mathrm{N}$ concentrations in the outflowing water on both soils (cf. Saarnio et al. 2018). At the same time, other anions $\left(\mathrm{NO}_{2}\right.$, $\left.\mathrm{PO}_{4}{ }^{3-}\right)$ were leached from the biochar. Both $\mathrm{NO}_{3}^{-}$and $\mathrm{NH}_{4}^{+}$are considered to be retained by ion exchange mechanisms (Fidel et al. 2018), but many factors like feedstock and pyrolysis temperature of biochar, $\mathrm{pH}$ of solution, availability of other ions in the solution and development of biochar functional groups over time affect the retention efficiency of those nutrients (Hale et al. 2013, Wang et al. 2015, Fidel et al. 2018). Microbial N utilization may also contribute to N dynamics in biochar amended soils (e.g. Bruun et al. 2012). During the last leaching occasion, the majority of the retained $\mathrm{NO}_{3}{ }^{-}$ was released from the pure biochar to the deionised water but only some of the retained $\mathrm{NH}_{4}^{+}$. These findings indicate that the retention and release behavior of different $\mathrm{N}$ ions to biochar is different, but overall our biochar leads to a significant decrease in total $\mathrm{N}$ leaching from sandy soils.

Soil texture also affected nutrient leaching. On the sandy till, the significant biochar-mediated decrease in the amount of outflowing water compensated for the significant increase in $\mathrm{PO}_{4}^{3-}-\mathrm{P}$ and total $\mathrm{P}$ concentrations in the outflowing water. Thus, the difference in the amount of leached $\mathrm{PO}_{4}{ }^{3-} \mathrm{P}$ and total $\mathrm{P}$ between the biochar treatments became non-significant. In the case of $\mathrm{NH}_{4}{ }^{+}-\mathrm{N}$ and $\mathrm{NO}_{2}^{-}-\mathrm{N}$, the difference in concentrations was so high that the decrease in run-off was not high enough to compensate for the enhanced leakage of those compounds. On the medium fine sand, biochar tended to increase rather than decrease leaching, although the soil contained less organic matter than the sandy till. Although this increase was non-significant during all three samplings, it changed some indicative differences in the concentrations to significant differences in the amount of leached nutrients. These results indicate that biochar can affect nutrient leaching in sandy soils rich in organic matter and that the effect is more pronounced on soils with a coarser texture due to increased water retention. Our findings are in agreement with the study of Abel et al. (2013) in which measurements on different soils with several applications of biochar showed that the more biochar was added to the soil the higher the water retention; more so on coarser (sands) than finer (loamy sands) soils.

\section{Biochar enhances decomposition of N-rich litter}

In the sandy till, mass loss of cellulose was higher than that of the shoots of $P$. pratense and the decomposition rate was over twice as high for cellulose than for $P$. pratense. This is not surprising as pure cellulose is easier to decompose than plant material, which consists of various compounds including lignin. In addition, the $\mathrm{N}$ content of the P. pratense litter was very low (cf. Kettunen et al. 2005, 2007b). In the study of Cui et al. (2017), microbes utilized N-poor (1.41\%) litter but biochar addition only (non-significantly) enhanced the cumulative respiration. In mesocosm experiments with the same biochar and soil types as in this study, the biochar had only a minor and temporary impact on enzyme activities in the soil (Niemi et al. 2015) and it increased microbial respiration only during dry conditions by increasing the soil moisture content (Saarnio et al. 2013). These minor effects in microbial activity support the non-significant biochar effect on litter decomposition on sandy till in this experiment.

In the medium fine sand, the decomposition rate was almost the same for both litter types. The difference in results between soil types is probably explained by the difference in the $\mathrm{N}$ content of the $P$. pratense litter between experiments, as $\mathrm{N}$ content has been shown to correlate positively with the decomposition rate of grass litter (e.g. Pastor et al. 1987, Ball and Drake 1997). In the medium fine sand experiment, the $\mathrm{N}$ content in the shoot litter was around five times higher than that of the litter used in the sandy till experiment and comparable to the $\mathrm{N}$ content of legumes (Trifolium pratense) and P. pratense grown with T. pratense (Kettunen et al. 2007a). In addition, the C:N ratio of the medium fine sand was lower than that of the sandy till. Under those favorable $\mathrm{N}$ conditions, 
the decomposition rate of shoots was possibly promoted by biochar induced changes in soil conditions (e.g. increased soil moisture and $\mathrm{PO}_{4}^{3-}-\mathrm{P}$ availability). Also, other differences in litter or soil quality may have affected the variability in litter decomposition between soil types.

\section{Conclusions}

Our experiments indicate that soil type and litter type dictate how biochar addition will affect water and nutrient leaching and litter decomposition. Biochar addition did not affect the decomposition rate of N-poor litter on sandy till, but increased the decomposition by $5 \%$ in medium fine sand. In addition, biochar may increase $\mathrm{N}$ and $\mathrm{P}$ availability in the soil both by releasing nutrients and by retaining water and nutrients. The biochar induced increase in $\mathrm{PO}_{4}^{3-}-\mathrm{P}$ and decrease in $\mathrm{NO}_{3}^{-}-\mathrm{N}$ concentrations in the leached water was stronger in the soil with the finer texture. On the other hand, biochar retained water very effectively in the soil with the coarser texture, which compensated for increased $\mathrm{PO}_{4}^{3-}-\mathrm{P}$ concentrations and intensified $\mathrm{NO}_{3}^{-}-\mathrm{N}$ retention. Our results indicate that even a moderate addition of biochar can effectively prevent $\mathrm{N}$ leaching from sandy soils rich in organic matter. However, modified biochars with the improved anion adsorption capacity are needed to prevent both $\mathrm{N}$ and $\mathrm{P}$ losses from agricultural soils.

\section{Acknowledgements}

This study was financed by the Ministry of Agriculture and Forestry. The English text was revised by David Wilson.

\section{References}

Abel, S., Peters, A., Trinks, S., Schonsky, H., Facklam, M. \& Wessolek, G. 2013. Impact of biochar and hydrochar addition on water retention and water repellency of sandy soil. Geoderma 202-203: 183-191. https://doi.org/10.1016/j.geoderma.2013.03.003

Angst, T.E. \& Sohi, S.P. 2013. Establishing release dynamics for plant nutrients from biochar. GCB Bioenergy 5: $221-226$. https://doi.org/10.1111/gcbb.12023

Ball, A.S. \& Drake, B.G. 1997. Short-term decomposition of litter produced by plants grown in ambient and elevated atmospheric $\mathrm{CO}_{2}$ concentrations. Global Change Biology 3: 29-35. https://doi.org/10.1046/j.1365-2486.1997.00091.x

Bruun, E.W., Ambus, P., Egsgaard, H. \& Hauggaard-Nielsen, H. 2012. Effects of slow and fast pyrolysis biochar on soil C and N turnover dynamics. Soil Biology and Biochemistry 46: 73-79. https://doi.org/10.1016/j.soilbio.2011.11.019

Coombs, J., Hall, D.O., Long, S.P. \& Scurlock, J.M.O. 1987. Techniques in Bioproductivity and Photosynthesis. Oxford: Pergamon Press. 298 p.

Cui, J., Ge, T., Kuzyakov, Y., Nie, M., Fang, C., Tang, B. \& Zhou, C. 2017. Interactions between biochar and litter priming: A threesource 14C and $\delta 13 C$ partitioning study. Soil Biology and Biochemistry 104: 49-58. https://doi.org/10.1016/j.soilbio.2016.10.014

Eurofins Viljavuuspalvelu Oy 2020. Viljavuustutkimuksen tulkinta. (in Finnish). https://cdnmedia.eurofins.com/european-east/ media/1818630/viljavuustutkimuksentulkinta2017teroprint.pdf (Accessed 13 January 2020)

Fidel, R.B., Laird, D.A. \& Spokas K.A. 2018. Sorption of ammonium and nitrate to biochars is electrostatic and pH-dependent. Scientific Reports 8: 17627. https://doi.org/10.1038/s41598-018-35534-w

Gao, S. \& DeLuca, T.H. 2016. Influence of biochar on soil nutrient transformations, nutrient leaching, and crop yield. Advances in Plants \& Agricultural Research 4: 348-362. https://doi.org/10.15406/apar.2016.04.00150

Glaser, B. \& Lehr, V.-I. 2019. Biochar effects on phosphorus availability in agricultural soils: A meta-analysis. Scientific Reports 9: 9338. https://doi.org/10.1038/s41598-019-45693-z

Hale, S.E., Alling, V., Martinsen, V., Mulder, J., Breedveld, G.D. \& Cornelissen, G. 2013. The sorption and desorption of phosphate-P, ammonium-N and nitrate-N in cacao shell and corn cob biochars. Chemosphere 91: 1612-1619. https://doi.org/10.1016/j.chemosphere.2012.12.057

Kerré, B., Willaert, B. \& Smolders, E. 2017. Lower residue decomposition in historically charcoal-enriched soils is related to increased adsorption of organic matter. Soil Biology and Biochemistry 104: 1-7. https://doi.org/10.1016/j.soilbio.2016.10.007

Kettunen, R., Saarnio, S., Martikainen, P.J. \& Silvola, J. 2005. Elevated CO concentration and nitrogen fertilisation effects on $\mathrm{N}_{2} \mathrm{O}$ and $\mathrm{CH}_{4}$ fluxes and biomass production of Phleum pratense on farmed peat soil. Soil Biology and Biochemistry 37: 739-750. https://doi.org/10.1016/j.soilbio.2004.09.010

Kettunen, R., Saarnio, S., Martikainen, P. J. \& Silvola, J. 2007a. Can a mixed stand of $\mathrm{N}_{2}$-fixing and non-fixing plants restrict $\mathrm{N}_{2} \mathrm{O}$ emissions with increasing $\mathrm{CO}_{2}$ concentration? Soil Biology and Biochemistry 39: 2538-2546.

https://doi.org/10.1016/j.soilbio.2007.04.023

Kettunen, R., Saarnio, S. \& Silvola, J. 2007b. $\mathrm{N}_{2} \mathrm{O}$ fluxes and $\mathrm{CO}_{2}$ exchange at different $\mathrm{N}$ doses under elevated $\mathrm{CO}_{2}$ concentration in boreal agricultural mineral soil under Phleum pratense. Nutrient Cycling in Agroecosystems 78: $197-209$.

https://doi.org/10.1007/s10705-006-9085-z 


\section{AGRICULTURAL AND FOOD SCIENCE}

Laird, D.A. 2008. The charcoal vision: A win-win-win scenario for simultaneously producing bioenergy, permanently sequestering carbon, while improving soil and water quality. Agronomy Journal 100: 178-181. https://doi.org/10.2134/agronj2007.0161

Lilja, H., Uusitalo, R., Yli-Halla, M., Nevalainen, R., Väänänen, T., Tamminen, P. \& Tuhtar, J. 2017. Suomen maannostietokanta. Käyttöopas. Luonnonvara- ja biotalouden tutkimus 6/2017. (in Finnish).

Mukherjee, A. \& Zimmerman, A.R. 2013. Organic carbon and nutrient release from a range of laboratory-produced biochars and biochar-soil mixtures. Geoderma 193-194: 122-130. https://doi.org/10.1016/j.geoderma.2012.10.002

Mukherjee, A., Zimmerman, A.R. \& Harris, W. 2011. Surface chemistry variations among a series of laboratory-produced biochars. Geoderma 163: 247-255. https://doi.org/10.1016/j.geoderma.2011.04.021

Niemi, R.M., Heiskanen, I. \& Saarnio, S. 2015. Weak effects of biochar amendment on soil enzyme activities in mesocosms in bare or Phleum pratense soil. Boreal Environment Research 20: 324-334.

Novak, J.M., Busscher, W.J., Laird, D.L., Ahmedna, M., Watts, D.W. \& Niandou, M.A.S. 2009. Impact of biochar amendment on fertility of a southeastern coastal plain soil. Soil Science 174: 105-112. https://doi.org/10.1097/SS.0b013e3181981d9a

Parvage, M.M., Ulén, B., Eriksson, J., Strock, J. \& Kirchmann, H. 2013. Phosphorus availability in soils amended with wheat residue char. Biology and Fertility of Soils 49: 245-250. https://doi.org/10.1007/s00374-012-0746-6

Pastor, J., Stillwell, M.A. \& Tilman, D. 1987. Little bluestem litter dynamics in Minnesota old fields. Oecologia 72: 327-330. https://doi.org/10.1007/BF00377559

Saarnio, S. 2016. Chapter 9. Impacts of biochar amendment on greenhouse gas emissions from agricultural soils. In: Guo, M., He, Z. \& Uchimiya, S.M. (eds). Agricultural and Environmental Applications of Biochar: Advances and Barriers. Madison, USA: SSSA Special Publication 63. p. 259-294. https://doi.org/10.2136/sssaspecpub63.2014.0045

Saarnio, S., Heimonen, K. \& Kettunen, R. 2013. Biochar addition indirectly affects $\mathrm{N}_{2} \mathrm{O}$ emissions via soil moisture and plant N uptake. Soil Biology and Biochemistry 58: 99-106. https://doi.org/10.1016/j.soilbio.2012.10.035

Saarnio, S., Räty, M., Hyrkäs, M. \& Virkajärvi, P. 2018. Biochar addition changed the nutrient content and runoff water quality from the top layer of a grass field during simulated snowmelt. Agriculture, Ecosystems \& Environment 265: 156-165. https://doi.org/10.1016/j.agee.2018.06.007

Wang, T., Camps Arbestain, M., Hedley, M. \& Bishop, P. 2012. Predicting phosphorus bioavailability from high-ash biochars. Plant and Soil 357: 173-187. https://doi.org/10.1007/s11104-012-1131-9

Wang, Z., Guo, H., Shen, F., Yang, G., Zhang, Y., Zeng, Y., Wang, L., Xiao, H. \& Deng, S. 2015. Biochar produced from oak sawdust by Lanthanum (La)-involved pyrolysis for adsorption of ammonium $\left(\mathrm{NH}_{4}^{+}\right)$, nitrate $\left(\mathrm{NO}_{3}^{-}\right)$, and phosphate $\left(\mathrm{PO}_{4}{ }^{3-}\right)$. Chemosphere 119: 646-653. https://doi.org/10.1016/j.chemosphere.2014.07.084

Yao, Y., Gao, B., Chen, J., Zhang, M., Inyang, M., Li, Y., Alva, A. \& Yang, L. 2013. Engineered carbon (biochar) prepared by direct pyrolysis of Mg-accumulated tomato tissues: Characterization and phosphate removal potential. Bioresource Technology 138: 8-13. https://doi.org/10.1016/j.biortech.2013.03.057

Yao, Y., Gao, B., Zhang, M., Inyang, M. \& Zimmerman, A.R. 2012. Effect of biochar amendment on sorption and leaching of nitrate, ammonium, and phosphate in a sandy soil. Chemosphere 89: 1467-1471. https://doi.org/10.1016/j.chemosphere.2012.06.002

Zhang, H., Chen, C., Gray, E.M., Boyd, S.E., Yang, H. \& Zhang, D. 2016. Roles of biochar in improving phosphorus availability in soils: A phosphate adsorbent and a source of available phosphorus. Geoderma 276: 1-6. https://doi.org/10.1016/j.geoderma.2016.04.020

Zimmerman, A.R., Gao, B. \& Ahn, M.-Y. 2011. Positive and negative carbon mineralization priming effects among a variety of biochar-amended soils. Soil Biology and Biochemistry 43: 1169-1179. https://doi.org/10.1016/j.soilbio.2011.02.005 